\title{
Kewajiban Penyidikan Oleh Penuntut Umum Dalam Perkara Tindak Pidana Perusakan Hutan
}

\author{
Syahrul Arif Hakim, Didik Endro Purwoleksono \\ dan Andi Surya Perdana \\ syahrularifhakim14@gmail.com \\ Universitas Airlangga
}

\begin{abstract}
Keywords: $\quad$ Abstract
Forest Destruction The investigation carried out by the Public Prosecutor after the Investigator (Police Crime; (PPNS) cannot complete the case file as referred to in Article 39 letter $b$ of Law No. Investigation; Pre- 18/2013 is not further explained in a separate article or an explanation of the scope of the Prosecution. investigative authority and the law also does not mention whether the investigation by the Public Prosecutor is a Continued Investigation or the public prosecutor conducts an investigation from the beginning. The investigation conducted by the public prosecutor in a case of criminal destruction is carried out in a stage known as the pre-prosecution. The duties of the Public Prosecutor in the Pre-Prosecution stage are initially to carry out their duties and authority to examine the case files submitted by the investigator and then provide instructions, based on the order of the law, they are obliged to carry out investigations for a certain period of time after the investigator is unable to complete the investigation either because the case files are not complete and / or The period of investigation carried out by the investigator is 60 (sixty) days and can be extended at the latest 30 (thirty) days has expired and if the obligations as referred to in Article 39 are not implemented, then according to Article 42 of Law No. 18 of 2013 concerning the Prevention and Eradication of Forest Destruction (P3H) may be subject to administrative sanctions.
\end{abstract}

Kata Kunci: $\quad$ Abstrak

Tindak Pidana Penyidikan yang dilakukan oleh Penuntut Umum setelah Penyidik (Kepolisian / Perusakan Hutan; PPNS ) tidak dapat melengkapi berkas perkara sebagaimana Pasal 39 huruf b UU Penyidikan; Pra No. 18 Tahun 2013 tidak dijelaskan lebih lanjut dalam pasal tersendiri maupun Penuntutan. penjelasan tentang ruang lingkup kewenangan penyidikan tersebut serta dalam undang-undang juga tidak disebutkan apakah penyidikan oleh Penuntut Umum ini termasuk Penyidikan Lanjutan atau penuntut umum melakukan penyidikan dari awal. Penyidikan oleh Penuntut Umum dalam perkara tindak pidana perusakan dilakukan dalam tahap yang dikenal istilahnya Pra Penuntutan. Tugas Penuntut Umum dalam tahap Pra Penuntutan yang awalnya melakukan tugas dan kewenangannya meneliti berkas perkara yang disampaikan penyidik dan selanjutnya memberikan petunjuk, berdasarkan perintah undang-undang wajib melakukan penyidikan dengan jangka waktu tertentu setelah penyidik tidak dapat menyelesaikan penyidikannya baik karena berkas perkara belum lengkap dan atau masa penyidikan yang dilakukan oleh penyidik selama 60 ( enam puluh ) hari dan dapat diperpanjang paling lama 30 (tiga puluh) hari telah habis dan jika kewajiban sebagaimana Pasal 39 tersebut tidak dilaksanakan, maka sesuai Pasal 42 UU No. 18 Tahun 2013 Tentang Pencegahan dan Pemberantasan Perusakan Hutan ( P3H ) dapat dikenakan sanksi administratif. 
Syahrul Arif, dkk: Kewajiban Penyidikan Oleh...

\section{Pendahuluan}

Untuk memastikan terpeliharanya kawasan hutan dalam pengelolaan dan pemanfaatannya, telah diundangkan UU No. 18 Tahun 2013 tentang Pencegahan dan Pemberantasan Perusakan Hutan. Undang-Undang ini lahir karena peraturan perundang-undangan yang ada belum secara tegas mengatur tindak pidana perusakan hutan yang dilakukan secara terorganisasi. Sementara itu, pemanfaatan dan penggunaan kawasan hutan harus dilaksanakan secara tepat dan berkelanjutan dengan mempertimbangkan fungsi ekologis, sosial, dan ekonomis serta untuk menjaga keberlanjutan bagi kehidupan sekarang dan kehidupan generasi yang akan datang. Pemerintah memberlakukan Undang Undang No. 18 Tahun 2013 tentang Pencegahan dan Pemberantasan Perusakan Hutan. Undang - undang yang pemikirannya sama dengan UU No. 41 Tahun 1999 Tentang Kehutanan ini, dalam pemberlakuannya hanya mencabut sebagian Pasal 50 dan sebagian Pasal 78 mengenai ketentuan pidana dalam Undang - undang Nomor 41 Tahun 1999 Tentang Kehutanan.

Pelaksanaan Undang-undang No. 18 Tahun 2013 Tentang Pencegahan Perusakan Hutan dilaksanakan dengan mengedepankan asas keadilan dan kepastian hukum, keberlanjutan, tanggung jawab negara, partisipasi masyarakat, tanggung gugat, prioritas serta keterpaduan dan koordinasi. Pembentukan Undang-undang ini selain memiliki aspek represif juga mempertimbangkan aspek restoratif yang bertujuan untuk:

a. memberikan payung hukum yang lebih tegas dan lengkap bagi aparat penegak hukum untuk melakukan pemberantasan perusakan hutan sehingga mampu memberi efek jera bagi pelakunya;

b. meningkatkan kemampuan dan koordinasi aparat penegak hukum dan pihakpihak terkait melalui lembaga pencegahan dan pemberantasan perusakan hutan dalam upaya pemberantasan perusakan hutan;

c. meningkatkan peran masyarakat dalam menjaga kelestarian hutan terutama sebagai bentuk kontrol sosial pelaksanaan pemberantasan perusakan hutan;

d. mengembangkan kerja sama internasional dalam rangka pemberantasan perusakan hutan secara bilateral, regional, ataupun multilateral; dan

e. menjamin keberadaan hutan secara berkelanjutan dengan tetap menjaga kelestarian dan tidak merusak lingkungan serta ekosistem sekitarnya guna 
mewujudkan masyarakat sejahtera. ${ }^{1}$

Guna meningkatkan efektivitas pemberantasan perusakan hutan, Undangundang No. 18 Tahun 2013 dilengkapi dengan hukum acara yang meliputi penyidikan, penuntutan, dan pemeriksaan di sidang Pengadilan. Salah satu yang diatur dalam Undang-undang ini adalah terkait dengan Penyidikan, yang mana Penyidikan Tindak Pidana Perusakan Hutan yang selama ini dilakukan oleh Penyidik Kepolisian atau PPNS diwajibkan kepada Penuntut Umum untuk melakukan penyidikan, hal ini sesuai dengan Pasal 39 UU No. 18 Tahun 2013 yang menyatakan:

Untuk mempercepat penyelesaian perkara perusakan hutan:

a. Penyidik wajib menyelesaikan dan menyampaikan berkas perkara kepada penuntut umum paling lama 60 (enam puluh) hari sejak dimulainya penyidikan dan dapat diperpanjang paling lama 30 (tiga puluh) hari;

b. Dalam hal hasil penyidikan belum lengkap, penuntut umum wajib melakukan penyidikan paling lama 20 (dua puluh) hari dan dapat diperpanjang paling lama 30 (tiga puluh) hari;

c. Penuntut umum wajib melimpahkan perkara ke pengadilan paling lama 25 (dua puluh lima) hari terhitung sejak selesai penyidikan;

Pasal tersebut diatas yang menerangkan kewenangan penyidikan oleh penuntut umum jika penyidik tidak mampu melengkapi hasil penyidikan sesuai dengan waktu yang ditentukan, baru dilaksanakan oleh Penuntut Umum dalam hal ini Kejaksaan Republik Indonesia pada Tahun 2017, yang mana Penuntut Umum Kejaksaan Tinggi Sumatera Selatan di bidang Pidana Umum membuat gebrakan melakukan penyidikan perkara tindak pidana Perusakan Hutan dengan Subyek hukum perserorangan dan subyek hukum korporasi ${ }^{2}$. Dan penyidikan oleh Penuntut Umum tersebut berhasil dilimpahkan ke tahap Penuntutan dan terbukti di persidangan.

\footnotetext{
${ }^{1}$ Lihat Penjelasan Undang - undang Nomor 18 Tahun 2013 Tentang Pencegahan dan Pemberantasan Perusakan Hutan.

2 Terbittop, 'Kejati Sumsel Buat Gebrakan, Sidik Praktik Ilegal Logging' (Terbittop.com, 2017) <https:/ / terbittop.com/2017/12/ kejati-sumsel-buat-gebrakan-sidik-praktik-illegal-logging/> accessed 14 September 2020.
} 
Keberhasilan Penuntut Umum Kejaksaan Tinggi Sumatera Selatan tersebut, selanjutnya diikuti oleh Penuntut Umum pada Jaksa Agung Muda Tindak Pidana Umum ( Jampidum ) Kejaksaan Agung RI yang juga melakukan Penyidikan setelah Penyidik PPNS tidak dapat melengkapi berkas perkara atas nama CV. EDOM ARIHA JAYA dan terbukti di persidangan.

Diakomodirnya kewenangan penuntut umum sebagaimana tercantum di dalam Pasal 39 huruf $\mathrm{b}$ tersebut, dimaksudkan untuk mempercepat penyelesaian perkara perusakan hutan dalam tahap penyidikan. Ketentuan tersebut menunjukkan adanya politik hukum dalam hukum positif di Indonesia yang memperbolehkan overlapping kewenangan penyidikan yang sebelumnya dilakukan oleh Kepolisian sebagaimana diatur dalam Undang - udang Nomor 8 Tahun 1981 tentang Hukum Acara Pidana yang selanjutnya KUHAP. ${ }^{3}$

Pengaturan kewenangan Penyidikan oleh Penuntut Umum dalam Undangundang ini tidak diatur dalam pasal tambahan maupun penjelasan undang undang dan juga tidak ada lagi aturan yang menjabarkan pelaksanaan penyidikan oleh penuntut umum terutama tugas. Penjelasan batasan - batasan kewenangan penyidikan oleh penuntut umum juga tidak dijelaskan sebagaimana mestinya dalam aturan pelaksanaan, serta pelaksanaan penyidikan oleh penuntut umum ini dapat diartikan sebagai penyidikan lanjutan atau penyidikan yang bisa dimulai dari awal, sehingga dikhawatirkan dikemudian hari jika tidak ada koordinasi dan komunikasi yang baik antara Penyidik Polri dan atau PPNS Kehutanan dengan Penuntut Umum dapat dikhawatirkan menimbulkan polemik ataupun tumpang tindih penyidikan.

Bertitik tolak dari uraian diatas, maka yang menjadi permasalahan dalam penelitian ini adalah sebagai berikut : Bagaimana mekanisme penanganan perkara tindak pidana perusakan hutan hingga dilakukan penyidikan oleh penuntut umum, Bagaimana pelaksanaan penanganan perkara tindak pidana perusakan hutan yang penyidikannya dilakukan oleh penuntut umum (Perkara Tindak Pidana Perusakan Hutan Atas nama CV. Edom Ariha Jaya).

\footnotetext{
3 Rendra, Gigih Benah, Kewenangan Penuntut Umum Dalam Penyidikan Perkara Pencegahan Pemberantasan Perusakan Hutan ( P3H ), Jurnal Yuridis Vol.6 No.2, Desember 2019.[3]
} 


\section{Mekanisme Penanganan Perkara Tindak Pidana Perusakan Hutan Hingga Dilakukan Penyidikan Oleh Penuntut Umum}

Penanganan perkara tindak pidana perusakan hutan dalam proses penyidikan diatur dalam Undang-undang No. 18 Tahun 2013 Tentang P3H , dalam Pasal 39 diatur selama 90 ( Sembilan puluh ) hari sejak dimulainya penyidikan dengan perincian 60 ( enam puluh) hari. Tahapan awal yang dilakukan oleh Penuntut Umum terhadap Penyidikan yang dilakukan oleh Penyidik disebut Tahap Prapenuntutan. Dalam ketentuan umum Kitab Undang-undang Hukum Acara Pidana (KUHAP) tidak dijelaskan apa pengertian dari Prapenuntutan. Istilah Prapenuntutan hanya ditemui dalam Pasal 14 huruf b KUHAP yang berbunyi demikian "Penuntut umum mempunyai wewenang mengadakan prapenuntutan apabila ada kekurangan pada penyidikan dengan memperhatikan Pasal 110 ayat (3) dan (4) dengan memberi petunjuk dalam rangka penyempurnaan penyidikan dari penyidik. Dengan demikian "prapenuntutan adalah wewenang Jaksa Penuntut Umum memberi petunjuk kepada penyidik dalam rangka penyempurnaan berkas perkara. ${ }^{4}$

Pengertian prapenuntutan dapat dibaca dalam penjelasan Pasal 30 ayat (1) huruf a UURI Nomor 16 Tahun 2004 yang berbunyi sebagai berikut: Prapenuntutan adalah tindakan jaksa untuk memantau perkembangan penyidikan setelah menerima pemberitahuan dimulainya penyidikan dari penyidik, mempelajari atau meneliti kelengkapan berkas perkara hasil penyidikan yang diterima dari penyidik serta memberikan petunjuk guna dilengkapi oleh penyidik untuk dapat menentukan apakah berkas perkara tersebut dapat dilimpahkan atau tidak ke tahap penuntutan.

Pengertian yang lain diberikan oleh A. Hamzah ${ }^{5}$ bahwa prapenuntutan ialah tindakan penuntut umum untuk memberi petunjuk dalam rangka penyempurnaan penyidikan oleh penyidik. Selanjutnya pengertian prapenuntutan yaitu tindakan Penuntut Umum untuk mengikuti perkembangan penyidikan setelah menerima pemberitahuan dimulainya penyidikan dari penyidik, mempelajari atau meneliti

\footnotetext{
4 Osman Simandjuntak, Teknik Penuntutan Dan Upaya Hukum (Kejaksaan Agung 1994).[6].

5 Andi Hamzah, KUHP DAN KUHAP (Revisi, Rineka Cipta 2008).[158].
} 
kelengkapan berkas perkara hasil penyidikan yang diterima dari penyidik serta memberi petunjuk guna dilengkapi oleh penyidik untuk dapat menentukan apakah berkas perkara tersebut lengkap atau tidak.

Dengan demikian dapat disimpulkan, baik dari ketentuan-ketentuan dalam KUHAP dan Peraturan perundang-undangan, pada dasarnya prapenuntutan adalah tindakan penuntut umum untuk: ${ }^{6}$

1. Mengikuti perkembangan penyidikan;

2. Menerima berkas perkara;

3. Mempelajari dan meneliti berkas perkara; dan

4. Memberikan petunjuk kepada penyidik untuk melengkapi berkas perkara.

Selain itu, dalam Surat Edaran Jaksa Agung Nomor B-401/E/9/93 Tanggal 08 September 1993 perihal pelaksanaan tugas prapenuntutan, juga disebutkan tugas prapenuntutan mengandung arti, tidak saja mencakup tugas penelitian berkas perkara dan pemberian petunjuk guna melengkapi berkas perkara, tetapi meliputi pula semua pelaksanaan tugas yang berkenaan dengan persiapan pelaksanaan tugas penuntutan. Dengan demikian dalam pengertian luas, prapenuntutan meliputi pelaksanaan tugas-tugas : Pemantauan perkembangan penyidikan, penelitian berkas perkara tahap pertama, pemberian petunjuk guna melengkapi hasil penyidikan, Penelitian ulang berkas perkara, Penelitian tersangka dan barang bukti pada tahap penyerahan tanggung jawab tersangka dan barang bukti yang dikenal dengan istilah Tahap II serta pemeriksaan tambahan. Sejak berlakunya Undang - undang No. 18 Tahun 2013 yang memberikan kewenangan kepada Penuntut Umum, maka Kejaksaan Republik Indonesia mengeluarkan Standar Operasional Penanganan Perkara Tindak Pidana Umum sebagaimana Peraturan Kejaksaan RI Nomor : 13 Tahun 2019 Tentang Pencabutan Peraturan Jaksa Agung Nomor : PER-036/A/JA/09/2011 Tentang Standar Operasional Prosedur (SOP) Penanganan Perkara Tindak Pidana Umum jo. Keputusan Jaksa Agung Republik Indonesia Nomor: KEP-24/E/Ejp/12/2019Tentang Standar Operasional Prosedur,

6 Aristo M.A. Pangaribuan, dkk, Pengantar Hukum Acara Pidana Di Indonesia (Rajawali Pers 2016) 11 2016).[114]. 
yang mana dalam SOP Pidum telah dilakukan pembaharuan prosedur penanganan yang salah satunya cara penuntut umum melakukan penyidikan terhadap tindak pidana perusakan hutan. Adapun mekanisme didalam prapenuntutan sebagai berikut:

a) Penerimaan Surat Pemberitahuan Dimulainya Penyidik (SPDP)

- Paling lambat 7 (tujuh) hari setelah dikeluarkan Surat Perintah Penyidikan, penyidik wajib menyampaikan Surat Pemberitahuan Dimulainya Penyidikan (SPDP) kepada kejaksaan, hal ini berdasarkan Putusan Mahkamah Konstitusi Nomor : 130/PUU-XIII/2015 Tanggal 11 Januari 2017 menyatakan Pasal 109 ayat (1) KUHAP bertentangan dengan Undang - undang Dasar Negara Republik Indonesia Tahun 1945 serta tidak mempunyai kekuatan hukum mengikat apabila frasa " penyidik " memberitahukan hal itu kepada Penuntut Umum" tidak dimaknai penyidik wajib memberitahukan dan menyerahkan SPDP kepada penuntut umum, terlapor dan korban dalam waktu paling lambat tujuh hari setelah dikeluarkan Surat Perintah Penyidikan ;

- Penerimaan SPDP dicatat dalam Register Penerimaan Pemberitahuan Dimulainya Penyidikan / Penghentian Penyidikan ( RP-9) ;

- Setelah penerimaan SPDP, diterbitkannya Surat Perintah Penunjukkan Jaksa Penuntut Umum untuk Penelitian dan Penyelesaian Perkara (P-16), jaksa yang ditunjuk untuk memantau perkembangan penyidikan;

- Sejak dikeluarkannya P-16, Jaksa Penuntut Umum yang bersangkutan secara aktif membina koordinasi dan Kerjasama positif dengan Penyidik melalui Forum Konsultasi Penyidik dan Penuntut Umum. Forum tersebut digunakan secara optimal untuk memberikan bimbingan / arahan kepada Penyidik, dengan maksud agar kegiatan penyidikan mampu menyajikan segala data dan fakta yang diperlukan bagi kepentingan penuntutan dan bolak-baliknya berkas perkara dapat dihindarkan.

b) Penerimaan Berkas Perkara Tahap Pertama

1. Penerimaan berkas perkara tersebut dicatat dalam Register penerimaan Berkas Perkara Tahap Pertama (RP-10) dan pelaporannya menggunanakan LP-6. Penelitian berkas perkara tahap pertama difokuskan kepada :

a. Kelengkapan Formal, yakni meliputi segala sesuatu yang berhubungan dengan formalitas/persyaratan, tata cara penyidikan yang harus dilengkapi dengan Surat Perintah, Berita Acara, Izin/persetujuan Ketua Pengadilan. Di samping penelitian kuantitas kelengkapan syarat formil, perlu diteliti pula segi kualitas kelengkapan tersebut yakni keabsahannya sesuai dengan ketentuan Undang - undang ;

b. Kelengkapan materiil, yakni kelengkapan informasi, data, fakta dan alat bukti yang diperlukan bagi kepentingan pembuktian. Kriteria yang dapat digunakan sebagai tolok ukur kelengkapan materiil antara lain : 
Syahrul Arif, dkk: Kewajiban Penyidikan Oleh...

- $\quad$ Apa yang terjadi (tindak pidana beserta kwalifikasi dan pasal yang dilanggar );

- Siapa pelaku, siapa - siapa yang melihat, mendemgar, mengalami peristiwa itu (tersangka, saksi - saksi / ahli);

- Bagaimana perbuatan itu dilakukan ( modus operandi );

- Dimana perbuatan itu dilakukan ( tempus delicti);

- Bilamana perbuatan dilakukan (locus delicti);

- Akibat apa yang ditimbulkannya (ditinjau secara viktimologis);

- Apa yang hendak dicapai dengan perbuatan itu (motivasi yang mendorong pelaku) Kelengkapan material terpenuhi bila segala sesuatu yang diperlukan bagi kepentingan pembuktian telah tersedia sebagai hasil penyidikan.

2. Pelaksanaan penelitian berkas perkara, dilakukan oleh Jaksa Peneliti yang tercantum dalam P-16 dan hasil penelitiannya dituangkan dalam Formulir Penelitian Berkas Perkara ( SOP Form-05) ;

3. Apabila menurut hasil penelitian :

a. ternyata hasil penyidikan telah lengkap, maka penuntut umum membuat Berita Acara Pendapat ( SOP Form-07 ), Rencana Surat Dakwaan (SOP Form-08) dan Penuntut Umum segera memberitahukan kepada Penyidik untuk segera menyerahkan tersangka dan barang bukti ( Tahap II Surat Pemberitahuan Hasil Penyidikan Sudah Lengkap ( P-21),

b. ternyata hasil penyidikan merupakan tindak pidana tetapi belum lengkap memenuhi syarat formil dan materiil maka Penuntut Umum memberitahukan kepada Penyidika dengan mengeluarkan Surat Pemberitahuan Hasil Penyidikan belum lengkap ( P-18 ) dalam waktu 7 (tujuh) hari sejak diterimanya berkas perkara dan dalam waktu 14 (empat belas hari) sejak diterimanya penyerahan Tahap pertama, Penuntut Umum mengembalikan berkas perkara tersebut dengan disertai petunjuk yang harus dilengkapi (P-19). Dalam P-19 agar diuraikan secara cermat, jelas dan lengkap tentang hal apa yang harus dilengkapi oleh penyidik sesuai ketentuan Pasal 138 ayat (2) jo. Pasal 110 ayat (2) dan (3) KUHAP yakni penyidik dalam waktu 14 (empat belas ) hari sejak tanggal penerimaan berkas perkara, penyidik harus sudah menyampaikan Kembali berkas perkara itu kepada penuntut umum. Petunjuk disusun dalam Bahasa sederhana dengan penggunaan kalimat - kalimat efektif.

c) Penelitian Berkas Perkara

Dari hasil koordinasi antara penyidik dan penuntut umum, penyidik melakukan penyidikan yang hasil penyidikan tersebut dituangkan dalam berkas perkara. Setelah penyidik merasa penyidikan telah cukup, maka penyidik menyerahkan berkas perkara kepada penuntut umum untuk diteliti apakah sudah memadai untuk dilakukan penuntutan. Tahap ini disebut sebagai tahap penelitian berkas perkara. 
Tahap penelitian berkas perkara akan sampai pada 3 (tiga) kemungkinan, yaitu:

1) Penuntut umum berpendapat berkas sudah lengkap

Bila berkas perkara sudah dinyatakan lengkap, maka penuntut umum mengeluarkan surat P-21 yang berarti berkas perkara dinyatakan lengkap. Dengan diterimanya berkas perkara oleh penuntut umum, maka tanggung jawab yuridis atas penanganan perkara tersebut beralih dari penyidik kepada penuntut umum. Setelah penyerahan berkas perkara (disebut juga sebagai penyerahan tahap I). Selanjutnya, penuntut umum segera membuat rencana surat dakwaan sebagai tahap awal dari penyusunan surat dakwaan dan segera memberitahukan penyidik untuk menyerahkan barang bukti dan juga tersangka kepada penuntut umum, dan dengan penyerahan ini beralih pula tanggung jawab yuridis terhadap tersangka dan barang bukti dari penyidik kepada penuntut umum (disebut juga penyerahan tahap II).

Penyerahan tersangka dan barang bukti harus dilakukan paling lama dalam jangka waktu 30 hari setelah berkas perkara djnyatakan lengkap. Bila dalam waktu 30 hari setelah berkas dinyatakan lengkap, penyidik tidak menindaklanjuti dengan menyerahkan tersangka dan barang bukti maka penuntut umum membuat pemberitahuan susulan bahwa penyidikan sudah lengkap, dan apabila dalam waktu 30 hari setelah adanya pemberitahuan susulan tersebut penyidik masih belum menyerahkan tersangka dan barang bukti maka demi kepastian hukum penuntut umum mengembalikan berkas perkara tersebut kepada penyidik.

2) Penuntut umum berpendapat berkas perkara merupakan tindak pidana tetapi belum lengkap

Apabila berkas perkara dari penyidik dinyatakan belum lengkap, maka penuntut umum memberitahukan dan mengembalikan berkas perkara kepada penyidik dengan disertai petunjuk terkait apa yang harus dilengkapi oleh penyidik. Penyidik dalam waktu 14 hari sudah harus menyampaikan kembali berkas perkara kepada penuntut umum.

Bila penuntut umum setelah menerima kembali berkas yang telah dilengkapi oleh penyidik berpendapat bahwa berkas perkara telah lengkap, maka penuntut umum selanjutnya melakukan tindakan sebagaimana dijelaskan dalam poin (1), namun bila penuntut umum berpendapat bahwa berkas perkara belum dilengkapi sesuai petunjuk penuntut umum, maka penuntut umum mengembalikan berkas perkara kepada penyidik untuk dilengkapi kembali. KUHAP tidak menjelaskan batasan berapa kali penuntut umum dapat terus memberikan petunjuk untuk melengkapi berkas perkara kepada penyidik. Untuk mencegah bolak-balik berkas perkara berkepanjangan, dalam Perja SOP Pidum diatur bahwa apabila bolak-balik berkas perkara sudah lebih dari 3 kali, maka penuntut umum harus memberikan petunjuk kepada penyidik agar penyidik menentukan sikap sesuai fakta hukum yang ditemukan dalam penanganan perkara tersebut sebagaimana petunjuk sebelumnya. 
Timbul pertanyaan, bagaimana apabila petunjuk dari penuntut umum tidak dapat dilengkapi oleh penyidik? Hal ini mungkin terjadi karena ketidakmampuan penyidik memenuhi petunjuk untuk melengkapi buktibukti dari penuntut umum, atau memang petunjuk yang diberikan oleh penuntut umum tidak mungkin dapat dipenuhi karena ketiadaan bukti atau keterangan yang diminta untuk dilengkapi.

Dalam kondisi seperti ini, ada dua kemungkinan. pertama adalah apabila penyidik telah berusaha sungguh-sungguh untuk melengkapi petunjuk penuntut umum namun tidak juga dapat terpenuhi, maka dalam Pasal 11 ayat (6) Perja Pedoman SOP Pidum, penuntut umum harus memberikan petunjuk kepada penyidik agar penyidik menentukan sikap sesuai dengan fakta hukum yang ditemukan dalam penanganan perkara tersebut sebagaimana petunjuk sebelumnya. ${ }^{7}$

Pengertian ini secara implisit mengandung makna agar penyidik menghentikan penyidikan, karena hasil penyidikan tidak kunjung dapat dilengkapi, terutama terkait kelengkapan bukti untuk membuktikan Unsur-unsur tindak pidana atau untuk membuktikan bahwa peristiwa tersebut merupakan suatu tindak pidana.

Kemungkinan kedua adalah apabila penyidik telah menyatakan optimal dalam melakukan penyidikan, namun tetap tidak dapat melengkapi petunjuk penuntut umum, maka penuntut umum yang bersangkutan mengajukan kepada Kepala Kejaksaan agar dilakukan pemeriksaan tambahan. Kemungkinan kedua ini dapat berujung pada penghentian perkara apabila setelah melakukan pemeriksaan tambahan, penuntut umum juga tidak dapat melengkapi berkas perkara, sebaliknya apabila penuntut umum berhasil melengkapi hasil penyidikan dalam berkas perkara, maka penuntut umum akan melimpahkan perkara tersebut ke pengadilan untuk dilakukan pemeriksaan.

3) Penuntut umum berpendapat bahwa berkas perkara bukan tindak pidana Apabila ternyata setelah menerima berkas perkara dari penyidik, setelah dilakukan penelitian penuntut umum berpendapat bahwa berkas perkara bukan tindak pidana maka penuntut umum sebelum menentukan Sikap harus melaksanakan gelar perkara sesuai dengan tingkatan kebijakan pengendalian penanganan perkara. Sikap penuntut umum setelah gelar perkara kemudian dituangkan dalam berita acara.

Dalam melakukan penelitian berkas perkara, penuntut umum harus memerhatikanjangka waktu untuk mempelajari dan meneliti berkas perkara yang diterima dari penyidik. Penuntut umum harus memberitahukan apabila terdapat kekurangan pada berkas perkara kepada penyidik dalam jangka waktu paling lama 7 hari terhitung sejak diterimanya berkas perkara dan paling lama 14 hari sejak diterimanya berkas perkara:

7 Lihat Ketentuan Pasal 11 ayat 6 Peraturan Jaksa Agung Nomor Per-036/A/JA/09/2011 Tentang Standar Operasional Penanganan Perkara Tindak Pidana Umum. 
penuntut umum harus mengembalikan berkas perkara beserta petunjuk yang harus dilengkapi kepada penyidik. ${ }^{8}$ Apabila dalam waktu 14 hari penuntut umum tidak mengembalikan hasil penyidikan kepada penyidik, maka penyidikan dianggap selesai atau dengan kata lain penuntut umum menerima berkas perkara dari penyidik. ${ }^{9}$

\section{Kewajiban Penyidikan Oleh Penuntut Umum Dalam Penyelesaian Perkara \\ Tindak Pidana Perusakan Hutan}

Berdasarkan Pasal 6 KUHAP disebutkan, Penyidik adalah:

a. Pejabat polisi negara Republik Indonesia;

b. Pejabat pegawai negeri sipil tertentu yang diberi wewenang khusus oleh undang-undang.

KUHAP memberikan kewenangan untuk melaksanakan tugas penyidikan kepada PPNS, di satu sisi akan memudahkan dalam pengungkapan suatu tindak pidana yang terjadi, mengingat banyaknya kendala yang dihadapi oleh aparat kepolisian untuk melakukan penyidikan, seperti kualitas dan kuantitas sumber daya manusia, sarana dan prasarana pendukung dan anggaran. ${ }^{10}$ Upaya mendudukkan PPNS sebagai lembaga mandiri dalam melakukan penyidikan suatu tindak pidana tampaknya bukan sekedar bahan pembicaraan semata, namun sudah mengarah pada pelembagaan.

Mengacu kepada Penjelasan Pasal 6 KUHAP yang dimaksud dengan" pejabat pegawai negeri yang ditunjuk secara khusus menurut Undang-undang tertentu yang diberi wewenang untuk melakukan penyidikan", ialah yang ditunjuk oleh perundang-undangan administrasi yang bersanksi pidana yaitu:

1. Pejabat Bea Cukai;

2. Imigrasi;

3. Tera;

4. Perikanan;

5. Lalu-lintas dan Angkutan Jalan;

6. Kejaksaan yang berwenang menyidik pelanggaran berat Hak Asasi Manusia;

8 Lihat Ketentuan Pasal 110 ayat 4 KUHAP dan 138 ayat 2 KUHAP.

Lihat Ketentuan Pasal 110 ayat 4 KUHAP.

10 Yurizal, 'Reformulasi Kewenangan Polri Dan PPNS Dalam Penyidikan Tindak Pidana Lingkungan Hidup' (Malang 2013).[76]. 
korupsi dan lain-lain;

7. Komisi Pemberantasan Korupsi yang berwenang menyidik tindak pidana korupsi;

8. Perwira Angkatan Laut yang berwenang menyidik pelanggaran di Zona Ekonomi Eksklusif.

Selain di atas, saya tambahkan termasuk juga penyidik yaitu Satuan Polisi Pamong Praja, untuk menyidik tindak pidana pelanggaran Peraturan Daerah. ${ }^{11}$

Didalam ketentuan Pasal 2 ayat (1) Undang-Undang Nomor 16 Tahun 2004 tentang Kejaksaan (UU Kejaksaan), disebutkan bahwa Kejaksaan Republik Indonesia adalah lembaga pemerintah yang melaksanakan kekuasaan negara di bidang penuntutan serta kewenangan lain berdasarkan undang-undang. ${ }^{12}$ Kejaksaan sebagai pengendali proses perkara (dominus litis), mempunyai kedudukan sentral dalam penegakan hukum, karena hanya institusi Kejaksaan yang dapat menentukan apakah suatu kasus dapat diajukan ke Pengadilan atau tidak berdasarkan alat bukti yang sah menurut Hukum Acara Pidana.

Seorang Jaksa dalam menjalankan tugasnya harus tunduk dan patuh pada tugas, fungsi, dan wewenang yang telah ditentukan dalam UU Kejaksaan. Tugas adalah amanat pokok yang wajib dilakukan dalam suatu tindakan jabatan. Sedangkan wewenang adalah pelaksanaan tugas yang berkaitan dengan kompetensi yurisdiksi baik kompetensi relatif maupun kompetensi mutlak. Dengan tugas dan wewenang, suatu badan dapat berfungsi sesuai dengan maksud dan tujuan badan tersebut. ${ }^{13}$

Dalam melaksanakan tugas dan wewenangnya, Kejaksaan membina hubungan kerjasama dengan badan penegak hukum dan keadilan serta badan negara atau instansi lainnya. ${ }^{14}$ Undang- undang Nomor 16 Tahun 2004 tentang Kejaksaan Republik Indonesia mengatur bahwa Kejaksaan mempunyai tugas dan wewenang melakukan penyidikan terhadap tindak pidana tertentu berdasarkan

\footnotetext{
${ }_{11}$ Didik Endro Purwoleksono, Hukum Acara Pidana (Airlangga University Press 2015).[60].

12 Marwan Effendy, Kejaksaan Republik Indonesia, Posisi Dan Fungsinya Dari Perspektif Hukum (Ghalia Indonesia 2007).[127].

13 ibid.[128].

14 Lihat Pasal 33 Undang-Undang Nomor 16 Tahun 2004 tentang Kejaksaaan Republik Indonesia
} 
undang- undang. ${ }^{15}$ Salah satu undang-undang yang memberikan kewenangan penyidikan yang dilakukan oleh penuntut umum adalah Undang-Undang Nomor 18 Tahun 2013 tentang Pencegahan dan Pemberantasan Perusakan Hutan.

Undang-Undang Nomor 18 Tahun 2013 tentang Pencegahan dan Pemberantasan Perusakan Hutan juga mengatur kewenangan penyidikan yang dilakukan oleh penuntut umum dalam kasus tindak pidana kerusakan Hutan. Kewenangan tersebut sebagaimana tercantum di dalam Pasal 39 huruf b yang menyatakan bahwa: "Dalam hal hasil penyidikan belum lengkap, penuntut umum wajib melakukan penyidikan paling lama 20 (dua puluh) hari dan dapat diperpanjang paling lama 30 (tiga puluh) hari".

Kewajiban kewenangan penuntut umum tersebut, dimaksudkan untuk mempercepat penyelesaian perkara pidana perusakan hutan dalam tahap penyidikan. Sedangkan pada Pasal 39 huruf b Undang- Undang Nomor 18 Tahun 2013 tentang Pencegahan dan Pemberantasan Perusakan Hutan yang wajib kepada penuntut umum untuk melakukan penyidik dalam hal hasil penyidikan belum lengkap dengan waktu paling lama dua puluh hari dan dapat diperpanjang tiga puluh hari.

Kewajiban penyidikan oleh Penuntut Umum dilakukan dalam rangka percepatan penyelesaian penanganan perkara perusakan hutan, bahkan didalam Pasal 42 Undang-Undang Nomor 18 Tahun 2013 tentang Pencegahan dan Pemberantasan Perusakan Hutan menentukan bahwa "Setiap pejabat yang tidak melaksanakan kewajiban sebagaimana dimaksud dalam Pasal 39, Pasal 40 dan Pasal 41 dikenai sanksi administratif sesuai dengan ketentuan peraturan perundang-undangan.

Dalam penanganan perkara tindak pidana umum, Penuntut Umum selain berpedoman kepada KUHAP juga berpedoman kepada aturan - aturan yang berlaku di lingkungan instansi Penuntut Umum yaitu Kejaksaan Republik Indonesia, dimana dalam penanganan perkara tindak pidana perusakan hutan Indonesia.

${ }^{15}$ Lihat Pasal 30 ayat (1) Undang-Undang Nomor 16 Tahun 2004 tentang Kejaksaaan Republik 
saat ini berpedoman pada:

- Keputusan Jaksa Agung RI Nomor : 518/A/J.A/11/2001 Tentang Perubahan atas Kepja Nomor : 132/JA/1/1/1994 Tentang Administrasi Perkara Tindak Pidana

- Peraturan Kejaksaan RI Nomor : 13 Tahun 2019 Tentang Pencabutan Peraturan Jaksa Agung Nomor : PER-036/A/JA/09/2011 Tentang Standar Operasional Prosedur (SOP) Penanganan Perkara Tindak Pidana Umum jo. Keputusan Jaksa Agung Republik Indonesia Nomor : KEP-24/E/Ejp/12/2019 Tentang Standar Operasional Prosedur.

Pasal 39 huruf b UU No. 18 Tahun 2013 Tentang P3H, yang mewajibkan Penuntut Umum melakukan penyidikan terhadap berkas perkara penyidik yang belum lengkap dapat diartikan bahwa Penuntut Umum wajib melakukan penyidikan sebagai berikut:

- Penyidikan yang dilakukan oleh Penyidik (Kepolisian / PPNS ) sampai dengan 90 (Sembilan puluh) hari masa penyidikan sudah maksimal memenuhi petunjuk penuntut umum dan berkas perkara yang dikirimkan penyidik tersebut oleh penuntut umum dinyatakan belum lengkap / tidak diterbitkan P-21;

- Penyidik (Kepolisian / PPNS ) sampai dengan waktu 90 ( Sembilan puluh ) hari masa penyidikan, penyidik pernah menyerahkan berkas perkara ( tahap I) kepada penuntut umum dan oleh berkas perkara tersebut diberikan petunjuk (P-18 dan P-19) , namun hingga berakhirnya masa penyidikan selama 90 (Sembilan puluh) hari, penyidikan tidak mengembalikan berkas perkara sehingga penuntut umum wajib untuk meminta kepada penyidik untuk menyerahkan berkas perkara yang mana terdiri dari berkas perkara penyidikan, tersangka dan barang bukti.

Penyidikan yang dilakukan oleh Penuntut Umum diartikan sebagai Penyidikan Lanjutan dalam hal Penuntut Umum melakukan penyidikan melengkapi kekurangan yang belum dipenuhi oleh Penyidik (Kepolisian / PPNS ) dan Penuntut Umum juga dapat diartikan melakukan penyidikan awal terhadap pengembangan perkara penyidikan awal dengan Batasan waktu penyidikan yang dilakukan oleh penuntut umum paling lama 20 (dua puluh ) hari dan dapat 
diperpanjang paling lama 30 ( tiga puluh ) hari.

Penyidikan yang dilakukan oleh Penuntut Umum juga berpedoman kepada KUHAP serta aturan - aturan yang berlaku dalam penyidikan, dimana Penuntut Umum dapat melakukan Penyidikan dengan prosedur:

- Penyidik Penuntut Umum mengirimkan Surat Pemberitahuan kepada Penyidik untuk melakukan Penyidikan;

- Penyidik Penuntut Umum dapat melakukan Penyitaan, Penahanan, Penggeledahan, Pemanggilan saksi maupun pemanggilan terdakwa.

\section{Analisis Kasus Kewenangan Penyidikan Penuntut Umum Dalam Penyelesaian Perkara Tindak Pidana Perusakan Hutan \\ Kasus Posisi}

Pada hari Senin tangal 7 Januari 2019, penyidik gabungan PPNS Kementrian Lingkungan Hidup dan Kehutanan telah mengamankan sebanyak 199 kontainer berisi kayu olahan jenis merbau yang diduga ilegal dengan menggunakan angkutan KM Selat Mas milik PT. Temas di Pelabuhan Lamong Surabaya. 199 kontainer tersebut KM Selat Mas dengan mengunakan dokumen yang terdiri dari 12 dokumen SKSHH-KO (dokumen yang menyertai pengangkutan kayu olahan nerupa kayu gergajian) dan 187 dokumen nota perusahaan. Adapun dari 199 kontainer tersebut sebanyak 27 kontainer merupakan milik CV. Edom Ariha Jaya dan Dedi Tandean anak dari Daniel Tandean yang merupakan direktur CV. Edom Ariha Jaya. CV. Edom Ariha Jaya mengirim sebanyak 27 kontainer berisi kayu gergajian (swan timber) dengan menggunakan 27 dokumen nota perusahaan dengan disertai lampiran daftar kayu olahan dengan produk yang tertera dalam nota perusahaan adalah flooring KD E2E, doorjam dan broti, namun berdasarkan pemeriksaan barang bukti kayu yang terdapat dalam 27 kontainer tersebut merupakan kayu gergajian sehingga terdapat ketidaksesuaian antara isi dokumen nota perusahaan dengan spesifikasi kayu yang diangkut.

Berdasarkan kejadian tersebut, terdakwa Dedi Tandean anak dari Daniel Tandean diduga melakukan tindak pidana perusakan hutan berupa mengubah 
status kayu hasil pembalakan liar seolah-olah menjadi kayu yang sah untuk dijual kepada pihak ketiga, baik di dalam maupun di luar negeri dan/atau mengedarkan kayu hasil pembalakan liar melalui darat, perairan, atau udara sebagaimana dimaksud dalam Pasal 12 huruf f Jo. Pasal 94 ayat (1) huruf d dan/atau Pasal 12 huruf I Jo. Pasal 86 ayat (1) huruf a Undang-Undang Nomor 18 Tahun 2013 tentang Pencegahan dan Pemberantasan Perusakan Hutan.

Penyidikan tindak pidana sebagaimana tersebuat diatas dilakukan oleh Penyidik Pegawai Negeri Sipil pada Kementrian Lingkungan Hidup dan Kehutanan (PPNS KLHK) berdasarkanSurat Perintah Penyidikan Nomor:SPRIN.DIK.07/PHP4/PPNS/2019 tanggal 18 Februari 2019. Pada tangal 08 April 2019, Penyidik PPNS KLHK melakukan penyerahan berkas perkara pidana atas nama Dedi Tandean anak dari Daniel Tandean kepada Penuntut Umum Kejaksaan Agung Republik Indonesia. Tanggal 17 Mei 2019, Penuntut Umum menyatakan bahwa hasil penyidikan yang dilaukan oleh PPNS KLHK dinyatakan belum lengkap, oleh sebab itu, berdasarkan Pasal 39 huruf b Undang-Undang Nomor 18 Tahun 2013 tentang Pencegahan dan Pemberantasan Perusakan Hutan, demi adanya kepastian hukum dan mempercepat penyelesaian terhadap proses penanganan perkara tersebut, maka Penuntut Umum meminta kepada Penyidik PPNS KLHK agar menyerahkan tersangka dan barang bukti untuk dilakukan penyidikan melengkapi berkas perkara. Untuk selanjutnya Penyidik PPNS KHLH menyerahkan penyidkan selanjutnya keada Penuntut Umum berdasarkan Berita Acara Pelimpahan Penyidikan. Kejaksaan Agung memalui Jaksa Agung Muda Tindak Pidana Umum kemudian mengeluarkan Surat Perintah Penyidikan dan memerintahkan beberapa Jaksa untuk melakukan penyidikan.

\section{Analisis Kasus}

Sebagai produk hukum yang disebut-sebut karya agung bangsa Indonesia, KUHAP memperkenalkan kerangka diferensiasi fungsional ${ }^{16}$, sedangkan kejaksaan

${ }^{16}$ Pasal 1 angka 1 KUHAP: Penyidik adalah pejabat polisi negara Republik Indonesia atau pejabat pegawai negeri sipil tertentu yang diberi wewenang khusus oleh undang-undang untuk melakukan penyelidikan. 
berfungsi hanya sebagai penuntut umum dan pelaksanaan penetapan hakim. Gagasan yang semula hendak dibangun dalam konsep diferensiasi fungsional tersebut adalah untuk melakukan suatu asas "penjernihan" (clarification) dan "modifikasi" (modification) fungsi dan wewenang antara setiap instansi penegak hukum, tanpa melupakan terbinanya saling kolerasi dan kordinasi dalam proses penegakan hukum yang saling berkaitan dan berkelanjutan antara satu instansi dengan instansi yang lain, sampai ke taraf permulaan penyidikan oleh kepolisian sampai kepada pelaksanaan putusan pengadilan oleh kejaksaan. Dalam hal ini selalu terjalin hubungan fungsi yang berkelanjutan, yang akan menciptakan suatu mekanisme saling "cheking" diantara sesama aparat penegak hukum dalam suatu rangkaian integrated criminal justice sistem. ${ }^{17}$

Namun demikian, dalam pelaksaanaannya, tujuan yang hendak dicapai tersebut menjadi sulit untuk dicapai, mongingat KUHAP memandang penyidikan sebagai suatu fungsi yang berdiri sendiri, sehingga memisahkan fungsi penyidikan di Indonesia dari hakikat sejatinya, yaitu sebagai bagian yang tidak terpisahkan yang bertujuan, untuk mendukung keberhasilan dari penuntutan perkara pidana. Dengan menempatkan masing-masing lembaga hukum yang terlibat dalam sistem peradilan pidana dalam kedudukan yang sejajar, maka tidak dimungkinkan bagi lembaga penegak hukum lain untuk secara langsung melakukan kontrol terhadap kebijakan-kebijakan yang diambil oleh pejabat yang berwenang dalam tahap pemeriksaan yang sedang berlangsung.

Dalam perjalanan dijumpai berbagai masalah yang memengaruhi kelancaran proses peradilan akibat kemandirian tersebut. Ketidaklancaran bukan saja mempengaruhi efisiensi, efektifitas, dan produktifitas peradilan, melainkan ancaman kegagalan dalam menjalankan sistem peradilan yang baik. Hal-hal semacam ini terjadi karena ada beberapa hal yang dilupakan, yaitu: ${ }^{18}$

${ }^{17}$ M. Yahya Harahap, Pembahasan Permasalahan Dan Penerapan KUHAP Penyidikan Dan Penuntutan (Sinar Grafika 2002).[47]. 2017).[45].

18 Jan. S. Maringka, Reformasi Kejaksaan Dalam Sistem Hukum Nasional (Sinar Grafika Offset 
1. Kebebasan suatu alat kelengkapan negara atau organ pemerintah yang mengandung muatan kekuasaan seperti kebebasan hakim dapat menjadi tempat berlindung bagi penyalahgunaan kekuasaan, bahkan kesewenangwenangan dalam menjalankan kekuasaan. Oleh karena itu diperlukan checks and balances antara berbagai organ dalam suatu organisasi. Namun fungsi saling mengontrol tidak dikenal lagi dalam tata peradilah kita karena masingmasing berdiri sendiri dan mengontrol diri sendiri.

2. Badan-badan penegak hukum yang mandiri bekerja untuk satu objek yang sama yaitu proses peradilan. Berbagai tahapan akan menentukan keberhasilan setiap tingkat proses selanjutnya, dan yang lebih penting akan menentukan output dari keseluruhan proses. Penolakan hakim atas suatu dakwaan, atau pengcmbalian hasil penyidikan oleh Jaksa kepada penyidik dapat dipandang sebagai bentuk kontrol. Dalam rangka kemitraan, harus dimungkinkan tahap saling memeriksa lebih awal, sehingga pada saat suatu perkara digelar, hanya ada satu saja persoalan yang perlu dipecahkan yaitu membuktikan terdakwa bersalah atau tidak bersalah.

3. Perkembangan secara berlebihan sifat dan sikap "ego sektoral". Masingmasing lembaga penegak hukum hanya bekerja untuk diri mereka sendiri. Ungkapan seperti "sudah selesai dari kami, terserah saja pada proses selanjutnya" merupakan cermin tidak berpikir dalam keseluruhan proses sebagai bentuk proses terpadu. Demikian pula sikap "menerima apa adanya" dengan segala akibatnya. Suatu dakwaan gagal, baik dalam bentuk menolak atau menyatakan batal dakwaan, membebaskan atau melepaskan terdakwa dari segala tuntutan, dapat terjadi karena keengganan hakim untuk memberi pendapat sebelum persidangan dimulai. Ada keengganan untuk secara seksama mempertimbangkan beberapa pendapat dari satuan penegak hukum lain karena merasa "diajari”. Untuk berhasilnya penuntutan maka diperlukan penyidikan yang berhasil pula. Sebaliknya, kegagalan dalam Penyidikan akan berakibat lemahnya berkas yang akan digunakan sebagai bahan penyusunan Surat Dakwaan. 
Disamping itu muncul tumpang tindih antar kewenangan penyidikan Kepolisian yang berdasarkan KUHAP merupakan penyidik untuk seluruh tindak pidana di Indonesia dengan kewenangan penyidikan yang dimiliki oleh berbagai Penyidik PNS. Menurut Andi Hamzah, saat ini ada sekitar 80 undang-undang yang memuat norma tentang PPNS. Salah satunya diatur dalam Undang-Undang Nomor 18 Tahun 2013 tentang Pencegahan dan Pemberantasan Perusakan Hutan.

Didalam perkembangannya, PPNS dikenal dalam bahkan semakin tumpang tindih dalam pengangkatan PPNS yang ternyata justru dilakukan oleh Menkumham. Menurut Pasal 2 ayat (5) PP No. 27 Tahun 1983 tentang Pelaksanaan KUHAP, PPNS diangkat oleh Menteri Kehakiman dengan terlebih dahulu mendengar pertimbangan Jaksa Agung dan Kepala Kepolisian Republik Indonesia. Tetapi dalam perkembangannya, fungsi penyidikan yang diemban oleh masing-masing penyidikan PPNS tersebut berpotensi menimbulkan tumpang tindihnya penanganan sebuah perkara yang bersifat multidimensi, baik antara sesama penyidik PPNS.

Menurut Pasal 7 ayat (2) KUHAP, Polri berfungsi sebagai koordinator penyidik bagi PPNS. Ketentuan tersebut juga terdapat dalam Pasal 14 ayat (1) huruf f UU No. 2 Tahun 2002 tentang Kepolisian Republik Indonesia yang mengatur kewajiban Polri melakukan koordinasi, pengawasan, dan pembinaan teknis terhadap PPNS. Namun demikian, kondisi tersebut juga menimbulkan permasalahan tersendiri, mengingat dalam praktiknya adanya hubungan koordinasi penyidik Polri dan PPNS Pun kerap menimbulkan masalah dalam praktik yang mengakibatkan tugas penyidikan PPNS kurang optimal. Misalnya, dalam banyak kasus kerap terjadi perebutan kewenangan penyidikan tindak pidana tertentu antara penyidik Polri dan PPNS. Dari berbagai kondisi tersebut jelaslah bahwa sistem koordinasi fungsi PPNS melalui satu pintu, yaitu Polri dirasakan tidak efektif dan justru menambah komplek permasalahan yang dihadapi dalam melakukan sinkronisasi fungsi penyidikan yang diemban oleh Penyidik PPNS sesuai dengan bidang tugasnya masing-masing.

Di lain pihak, Kejaksaan sebagai pengemban fungsi penuntutan, tidak memiliki hubungan koordinasi langsung dengan Penyidik PPNS mengingat 
menurut KUHAP kewajiban menyampaikan hasil penyidikan oleh PPNS kepada Kejaksaan harus melalui Penyidik Polri dan demikian pula sebaliknya penyampaian petunjuk dari Kejaksaan kepada PPNS dilakukan melalui Penyidik Polri. Kondisi tersebut menyebabkan lambat serta berbelit-belitnya proses penanganan perkara yang dilakukan oleh Penyidik PPNS jika dibandingkan penyidikan yang dilakukan oleh Penyidik Polri.

Dari berbagai uraian di atas, maka jelaslah bahwa bangunan penegakan hukum yang memisahkan antara fungsi penyidikan dan penuntutan dirasakan tidak dapat lagi menunjang kebutuhan akan efektifitas penanganan perkara di dataran praktis. Mengingat sejatinya penyidikan merupakan fungsi penunjang untuk mempersiapkan penuntutan yang baik, maka peranan untuk mengkoordiinasikan berbagai lembaga yang memiliki kewenangan penyidikan tersebut sudah seharusnya terlembaga pada Kejaksaan sebagai pelaksana fungsi penuntutan. Dalam konteks tersebut, Kejaksaan sebagai dominus litis dalam perkara pidana dapat secara efektif menilai mengenai ketentuan pidana mana yang akan digunakan dalam menangani sebuah perkara, termasuk lembaga mana yang paling tepat untuk melakukan penyidikan guna menunjang materi penuntutan yang sedang dipersiapkannya tersebut.

Sebagaimana kasus yang dianalisis penulis, langkah tepat telah diambil Penuntut Umum dalam penyelesaian perkara perusakan hutan. Demi tercapainya kepastian hukum dan percepatan peneyelesaian perkara, Penuntut Umum mengambil alih proses penyidikan sebagaimana diatur didalam Pasal 39 UndangUndang Nomor 18 Tahun 2013 tentang Pencegahan dan Pemberantasan Perusakan Hutan. Hal tersebut juga sesuai dengan posisi kejaksaan sebagai dominus litis dalam penanganan suatu perkara serta semangat extra ordinary untuk mempercepat penanganan perkara. Selain itu, kewenangan penuntut umum dalam melakukan penyidikan lanjutan dalam tindak pidana perusakan hutan dilatarbelakangi karena belum efektifnya proses koordinasi antara Penyidik dan Penuntut Umum yang mengakibatkan permasalahan dalam penyidikan kasus perusakan hutan tidak berjalan efektif. 
Kewenangan Penuntut Umum dalam melakukan penyidikan perkara perusakan hutan merupakan solusi yang tepat untuk melengkapi berkas perkara yang belum lengkap sehingga secara langsung dapat memperlancar dan memepercepat proses penanganan perkara dan memberikan rasa keadilan dan kepastian hukum bagi tersangka. Namun agar dapat diaplikasikan dan memenuhi tujuan dari upaya percepatan penanganan perkara perusakan hutan sehingga mencerminkan kepastian dan Keadilan dan Kemanfaatan maka perlu disusun ketentuan teknis melalui produk hukum berupa Peraturan Pemerintah, peraturan Jaksa Agung maupun dalam bentuk MoU.

\section{Kesimpulan}

Dalam penanganan perkara tindak pidana perusakan hutan, fungsi prapenuntutan yang dilakukan oleh penuntut umum setelah menerima pemberitahuan dimulainya penyidikan dari penyidik, mempelajari atau meneliti kelengkapan berkas perkara hasil penyidikan dari penyidik serta memberikan petunjuk guna dilengkapi oleh penyidik untuk dapat menentukan apakah berkas perkara tersebut lengkap atau tidak, dan apabila penuntut umum menyatakan berkas perkara tindak pidana perusakan hutan belum lengkap dan penyidik menyatakan telah maksimal melakukan penyidikan maka penuntut umum wajib meminta kepada penyidik untuk melimpahkan kewenangan penyidikanya kepada penuntut umum, dan juga apabila penuntut umum sampai dengan 90 ( Sembilan puluh ) hari belum menyatakan berkas perkara lengkap, maka penuntut umum wajib melakukan penyidikan terhadap perkara tindak pidana perusakan hutan tersebut dengan jangka waktu selama 20 ( dua puluh) hari dan dapat diperpanjang selama 30 ( tiga puluh ) hari.

Penyidikan yang dilakukan oleh Penuntut Umum dapat disebut dengan penyidikan lanjutan yang pelaksanaanya berdasarkan KUHAP untuk perkara yang penyidikannya belum lengkap dan Penuntut Umum juga dapat melakukan penyidikan awal dengan mengirimkan Surat Pemberitahuan Dimulainya Penyidikan ( SPDP) terhadap pengembangan perkara baru atas perkara yang awal 
dengan kewenangan penuntut umum dapat melakukan sebagaimana kewenangan penyidik seperti melakukan penahanan, penyitaan, penelusuran asset dan kewenangan penyidik lainnya selama Penuntut Umum tersebut dapat melakukan Penyidikan dengan jangka waktu paling lama 50 ( lima puluh ) hari tersebut.

Ketentuan Pasal 39 huruf b tentang kewenangan penyidikan oleh penuntut umum hingga saat ini tidak terdapat pasal penjelasan serta belum ada aturan pelaksana dari UU No. 18 Tahun 2013 Tentang P3H yang mengatur sebagaimana diaturnya pemeriksaan tambahan yang dapat dilakukan oleh Jaksa yang terdapat dalam UU No. 16 Tahun 2004, sehingga ke depannya pemerintah dapat mengatur lebih lanjut kewenangan Penuntut Umum melakukan Penyidikan untuk perkara - perkara tindak pidana tertentu sehingga dapat menciptakan fungsi pengawasan kewenangan sehingga terwujud system peradilan pidana terpadu (Integrated Criminal Justice System).

\section{Daftar Bacaan}

\section{Buku}

Andi Hamzah, KUHP DAN KUHAP (Revisi, Rineka Cipta 2008).

Aristo M.A. Pangaribuan, dkk, Pengantar Hukum Acara Pidana Di Indonesia (Rajawali Pers 2016) 11 2016).

Didik Endro Purwoleksono, Hukum Acara Pidana (Airlangga University Press 2015).

Jan. S. Maringka, Reformasi Kejaksaan Dalam Sistem Hukum Nasional (Sinar Grafika Offset 2017).

M. Yahya Harahap, Pembahasan Permasalahan Dan Penerapan KUHAP Penyidikan Dan Penuntutan (Sinar Grafika 2002).

Marwan Effendy, Kejaksaan Republik Indonesia, Posisi Dan Fungsinya Dari Perspektif Hukum (Ghalia Indonesia 2007).

Osman Simandjuntak, Teknik Penuntutan Dan Upaya Hukum (Kejaksaan Agung 1994). 


\section{Jurnal}

Rendra, Gigih Benah, Kewenangan Penuntut Umum Dalam Penyidikan Perkara Pencegahan Pemberantasan Perusakan Hutan ( P3H ), Jurnal Yuridis Vol.6 No.2, Desember 2019.

\section{Laman}

Terbittop, 'Kejati Sumsel Buat Gebrakan, Sidik Praktik Ilegal Logging' (Terbittop. com, 2017) <https://terbittop.com/2017/12/kejati-sumsel-buat-gebrakansidik-praktik-illegal-logging/> accessed 14 September 2020.

Tesis

Yurizal, 'Reformulasi Kewenangan Polri Dan PPNS Dalam Penyidikan Tindak Pidana Lingkungan Hidup' (Malang 2013).

\section{Perundang-undangan}

Undang-undang No. 08 Tahun 1981 Tentang Hukum Acara Pidana.

Undang-undang No. 18 Tahun 2013 Tentang Pencegahan dan Pemberantasan Perusakan Hutan.

Keputusan Jaksa Agung RI Nomor : 518/A/J.A/11/2001 Tentang Perubahan atas Kepja Nomor : 132/JA/1/1/1994 Tentang Administrasi Perkara Tindak Pidana.

Peraturan Kejaksaan RI Nomor : 13 Tahun 2019 Tentang Pencabutan Peraturan Jaksa Agung Nomor: PER-036/A/JA/09/2011 Tentang Standar Operasional Prosedur (SOP) Penanganan Perkara Tindak Pidana Umum jo. Keputusan Jaksa Agung Republik Indonesia Nomor : KEP-24/E/Ejp/12/2019 Tentang Standar Operasional Prosedur.

How to cite: Syahrul Arif Hakim, Didik Endro Purwoleksono dan Andi Surya Perdana, 'Kewajiban Penyidikan Oleh Penuntut Umum Dalam Perkara Tindak Pidana Perusakan Hutan' (2020) Vol. 3 No. 3 Media Iuris. 
--Halaman ini sengaja dibiarkan kosong-- 